\title{
8. MASS PHYSICAL PROPERTIES OF PLIOCENE TO QUATERNARY SEDIMENTS IN THE GULF OF CALIFORNIA, DEEP SEA DRILLING PROJECT LEG 64
}

\author{
Gerhard Einsele, Geologisches Institut der Universität Tübingen, Sigwartstrasse 10, Federal Republic of Germany
}

\begin{abstract}
The Pliocene-Quaternary sediments that we drilled at eight sites in the Gulf of California consist of silty clays to clayey silts, diatomaceous oozes, and mixtures of both types. In this chapter I have summarized various measurements of their physical properties, relating this information to burial depth and effective overburden pressure. Rapid deposition and frequent intercalations of mud turbidites may cause underconsolidation in some cases; overconsolidation probably can be excluded. General lithification begins at depths between 200 and 300 meters sub-bottom, at porosities between 55 and $60 \%$ (for silty clays) and as high as 70\% (for diatomaceous ooze). Diatom-rich sediments have low strength and very high porosities (70-90\%) and can maintain this state to a depth of nearly 400 meters (where the overburden pressure $=1.4 \mathrm{MPa}$ ). The field compressibility curves of all sites are compared to data published earlier (Fig. 8 ). Where sediments are affected by basaltic sills, these curves clearly show the effects of additional loading and thermal stress (diagenesis near the contacts). Strength measurements on well-preserved hydraulic piston cores yielded results similar to those obtained on selected samples from standard drilling. Volumetric shrinkage dropped to low values at 100 to 400 meters burial depth ( 0.3 to $2.0 \mathrm{MPa}$ overburden pressure). Porosity after shrinkage depends on the composition of sediments.
\end{abstract}

\section{INTRODUCTION}

Measuring mass physical properties of both soft and indurated sediments and hard rock samples is routine aboard the Glomar Challenger. General problems related to core disturbances, use of special methods, evaluation of measurements, and the like have been extensively described in previous reports of the DSDP (e.g., Bennett and Keller, 1973; von Huene et al., 1973; Lee, 1973; Demars et al., 1979) and elsewhere. We followed these recommendations as far as possible. The samples were carefully selected, measurements being carried out mainly on the usually less-disturbed lowermost section of the cores or on undisturbed indurated "biscuit" pieces or chunks surrounded by drilling breccia.

In addition to the standard drilling method, we had the opportunity to use the newly developed SerockiStorm-Cameron hydraulic piston corer for the first time. Most cores thus obtained were excellently preserved (see Sites 477, 480, and 481 site chapters, this volume, Pt. 1, hereafter cited "this volume"), and we could compare results from these samples with those from samples gained by the standard drilling method. Furthermore, some of our methods varied somewhat from and were more extensively used than those on previous legs (e.g., the cylinder method for bulk density and porosity determinations); shrinkage of sediments was determined for the first time on about 100 samples. On the other hand, because of various constraints, several standard methods used on some previous DSDP legs were not applied, e.g., the determination of Atterberg limits or consolidation tests.

On Leg 64, measurements of physical properties included the determination of about 340 water contents

\footnotetext{
${ }^{1}$ Curray, J. R., Moore, D. G., et al., Init. Repts. DSDP, 64: Washington (U.S. Govt. Printing Office).
}

and porosities as well as 365 bulk and grain densities on chunks. The same properties were determined on approximately 100 additional cylinder samples. We also carried out about 110 measurements of vane shear strength and 140 determinations of sound velocity.

The results at individual drilling sites are presented in the site chapters (this volume). In this chapter, I have summarized and interpreted in a general way data from all sites of Leg 64 and attempted to deal with some special problems encountered in the Pliocene to Quaternary sediments of the Gulf of California, namely: (1) high, but significantly changing proportions of biogenic silica in hemipelagic muds and their influence on mass physical properties; (2) state of consolidation and lithification; (3) variations of mass physical properties owing to the presence of sandy and chiefly muddy turbidites; (4) the influence of basaltic sills.

These questions are partially treated in Einsele and Kelts; and Einsele, (both this volume, Pt. 2, hereafter "this volume"); they are also considered in this summary.

\section{METHODS, DEFINITIONS, ERRORS}

Water Content, Bulk Density, and Porosity

These properties were determined by gravimetric methods described, for example, by Boyce (1976). Water content is related to the weight of the wet samples and has therefore been defined here as "wet water content." Similarly, bulk density is expressed as "wet-bulk density" of the original wet sediment, and buoyancy is not taken into account. The volume of the samples was measured either on chunks weighed in air and under water, or by taking cylinder samples of known volume. To apply the latter method on split cores, special cylinders made of stainless steel (volume about $5 \mathrm{~cm}^{3}$ ) were used. Immediately after taking the samples, the cylinders were sealed with caps to prevent evaporation. Some hours later they were weighed, including the wet samples. Wet water content and porosity were calculated from the water loss at $110^{\circ} \mathrm{C}$.

Porosity data are based on the assumption that the sediments were water saturated. This is not true for all samples, because some were affected by expanding gas after the in situ hydrostatic pressure at the sea 
bðttom had been released by bringing the cores up into the shipboard laboratory. In these cases, porosity values calculated from sample volume and water loss are somewhat too low (see also site chapter 474 , this volume). Furthermore, wet-bulk density as well as porosity data may be affected by the increase of volume (elastic "rebound") caused by the removal of the samples from their in situ overburden pressure (Hamilton, 1976). Therefore, shipboard laboratory values of porosity tend to become too high and values of bulk density too low. For diatomaceous oozes this error is comparatively small, particularly in the upper 50-100 meters of the sediment, but it increases with greater depth. According to Hamilton, for diatomaceous ooze taken from 500 meters sub-bottom, the increase of porosity by rebound amounts to about $3 \%$. Our data are, however, not corrected for rebound, since all but one drilling holes were shallower than 500 meters and since other factors such as changing composition of the sediments affect physical properties much more than does rebound. Furthermore, rebound may be considerably smaller than that determined by Hamilton, when very stiff or hard claystones are investigated, which already are affected by beginning diagenesis, i.e., the onset of cementation at grain contacts (see, for example, von Huene, et al., 1973).

All porosity data are corrected for salt content (see, for example, Boyce, 1977). According to chemical analyses on interstitial water (see chapters on inorganic chemistry, this volume, Pt. 2), the total salt content of the interstitial water of sediments down to the depths explored by drilling varies only slightly. Therefore, no special corrections for changing salt content were necessary.

Wet-bulk density was also determined by gamma-ray attenuation techniques on unsplit cores, referred to as GRAPE measurement (Bennett and Keller, 1973; Boyce, 1977). If these contain relatively undisturbed sediment, then the GRAPE analog graphs recording computer corrected wet-bulk densities agree well with values found by gravimetric methods. GRAPE measurements also have been useful in detecting abrupt density changes at the base of mud turbidites (see following discussion, as well as Einsele and Kelts, this volume).

Porosity calculations from GRAPE data may be greatly in error if grain densities are not accurately known (Boyce, 1977). For this reason, and because sufficient porosity data from selected relatively undisturbed samples could be gained by gravimetric methods, GRAPE porosity was not determined.

\section{Grain Density}

Grain density was determined by two methods: (1) shipboard measurements on chunk samples (see site chapter 474); and (2) pycnometer method (direct measurement) in the Laboratory of the Geological Institute of Tübingen University. Both methods yield mean values for all grains composing the sediment. Method 1 is reliable only when samples are water saturated, which, because of expanding gas, was not always true. While samples were being weighed under water, however, unsaturated samples may have taken up water, thereby reducing the error caused by gas-filled pore space.

\section{Shrinkage}

Shrinkage $(S h)$ was not determined on previous DSDP legs. It is the loss of volume expressed as a percentage of the original volume, $V_{o}$, after wet cylinder samples have been dried at $110^{\circ} \mathrm{C}$. The volume of the shrunken cylindrical samples, $V_{s}$, is determined by measuring mean diameter and height. Then shrinkage is:

$$
S h=\frac{V_{o}-V_{s}}{V_{o}} \cdot 100(\%)
$$

Because the shrunken samples no longer represent ideal geometrical cylinders, but are often somewhat contorted, the determination of $V_{s}$, and therefore also of $S h$, is not very accurate. Nevertheless, the values of shrinkage may provide valuable information about the composition and initial diagenesis of the sediments.

\section{Vane Shear Strength}

To measure vane shear strength of clayey sediments, we primarily used the modified Wykeham Farrance laboratory vane apparatus. The method is described in detail by Boyce (1977) and Rocker (1974). As suggested by Perlow and Richards (1977), stress is applied to the spring at a rate of $89^{\circ}$ per minute $(=0.026 \mathrm{rad} / \mathrm{s}$, conversion factor; see Richards, 1974) so that the shear test is fast enough to prevent the sample from draining. The vane we used was $1.28 \mathrm{~cm}$ high and had the same diameter. All measurements were carried out at least twice on split cores with the vane axis oriented parallel to the bedding of the sediments. The highest value of two or several tests was taken as representative of the core section. The blades were buried 0.7 to $1.0 \mathrm{~cm}$, and we applied no correction for the buried part of the vane rod. Because of time constraints remolded shear strength was not measured. Determining remolded shear strength and calculating the sensitivity of the clay minerals as an indicator makes sense only so long as diagenesis has not yet started. Furthermore, the way in which remolding and retesting has to be performed with the vane is somewhat controversial (Richards, 1974).

For stronger consolidated sediments (usually described as mudstones), a hand-operated Soiltest high-capacity vane tester or a newly developed one with cone-shaped vane blades was used. In these cases, the cores often had been split by saw and many of the mudstones cracked during the vane test. Nevertheless, we usually finished the test by holding the split pieces together by hand until a cylindrical specimen had been sheared off. The shear values gained under such circumstances therefore tend to be too low and questionable. But since several tests were always performed at the same core section, from which the highest shear value was taken as representative, many of the values of the hand-operated shear test may give the correct order of magnitude. The limit of these tests is reached when the sediments become too hard to allow the blades to be pressed by hand into the samples. At this point no further shipboard shear tests are possible.

Residual negative pore water pressures that may affect the laboratory shear strength data (see Lee, 1973 and the following discussion) could not be measured.

\section{Sound Velocity}

We measured compressional sound velocity through sediments and basaltic rocks with the shipboard Hamilton Frame velocimeter at 400 $\mathrm{kHz}$ (for a description of the equipment and technique see Boyce, $1975,1976)$. The sound velocity of weak sediments was determined through the core liner where the core was little disturbed. We determined a special correction factor for the thickness of the core liner. We obtained isolated chunks from stiff sediments and smoothed them by knife to generate parallel acoustic contacts with the transducers. Many samples were soaked in seawater to saturate the pores filled by expanded gas. Despite this, the attenuation of sound often remained too great for us to get a reliable velocity measurement. Hard rocks were cut by saw and also soaked in seawater, before being measured in the Hamilton Frame at room temperature. No special attempt was made to check the correction factor determined earlier for the oscilloscope. The sound velocities repeatedly measured through standard samples of lucite and aluminum were of the right order of magnitude.

\section{MASS PHYSICAL PROPERTIES VERSUS DEPTH}

The standard and most simple procedure is plotting mass physical properties versus depth below seafloor. Figure 1 shows the trend curves for wet water content and porosity of all sites investigated. These curves are eye-fitted lines through the somewhat scattering data points. Though the single data points of these and all the other curves presented here are omitted, they do appear in the graphs for mass physical properties in the site chapters (this volume). The trend lines often correspond more or less with the middle to upper part of mud turbidites, which constitute the major part of the basinal sediments of Sites $474,477,478$, and 481 .

Since the curves for water content and porosity of the same drilling hole run more or less parallel, the diagrams look very similar. At given depths below the seafloor, however, the scatter of data from different holes is considerable, even if we exclude those holes in which basaltic sills were encountered. It is mainly at Site 474 where water content and porosity are lower by about $10 \%$ over the total depth range. The reason for this de- 

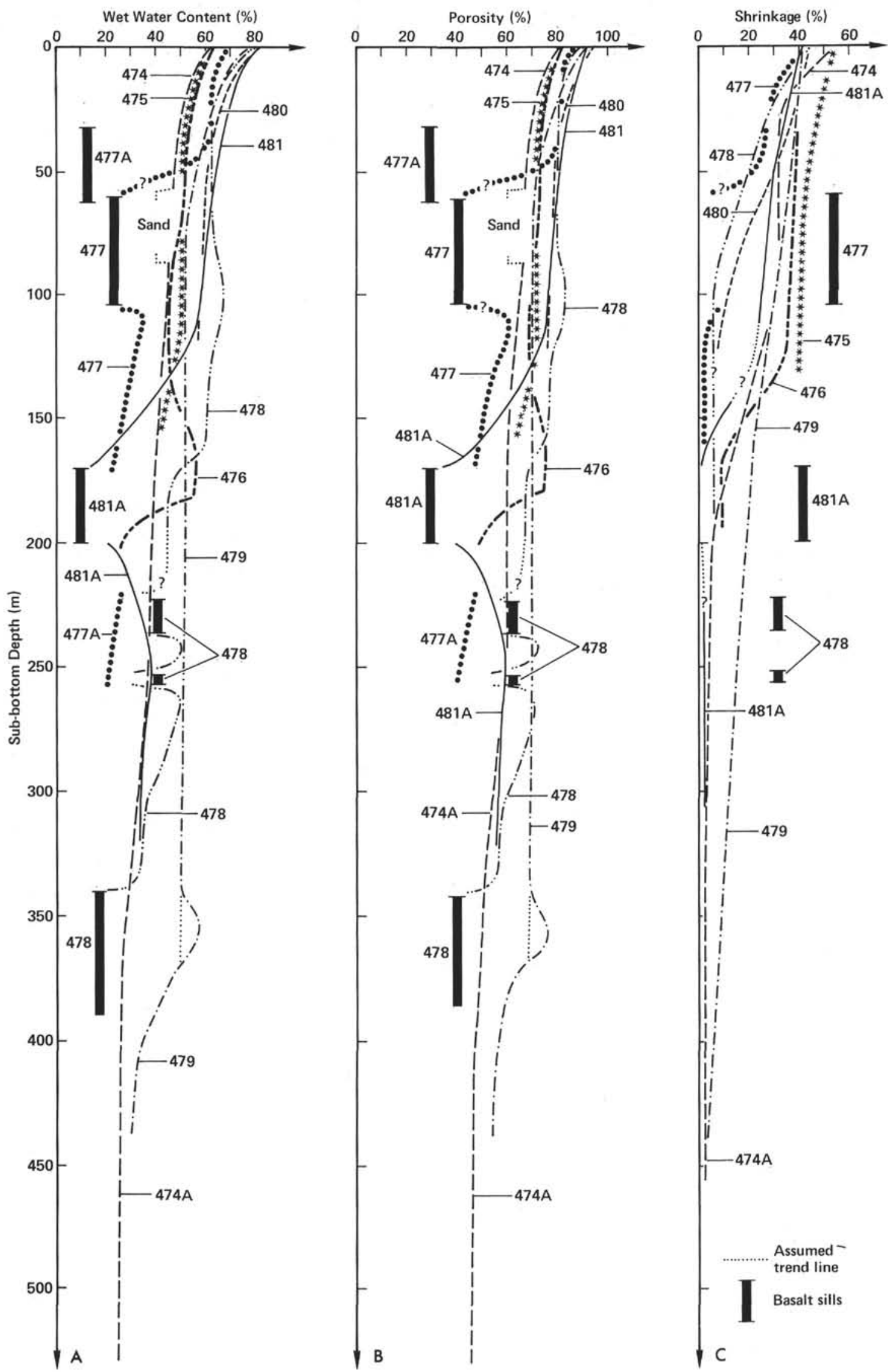

Figure 1. $\mathrm{A}=$ wet water content, $\mathrm{B}=$ porosity, and $\mathrm{C}=$ shrinkage of sediments versus depth (at all sites of Leg 64 ). 
viation from the general trend may be the relatively large proportion of sands (presumably chiefly turbidites) in the upper part of the sequence as well as the low percentage of biogenic silica, compared to other holes. There is no doubt that a high content of fine-grained skeletal opaline silica (chiefly diatoms) preserves high porosities (up to about 70\%) and water content (about $50 \%$ ) at a depth of 350 to 400 meters (Site 479 , see also site chapter). Layers containing more than $50 \%$ diagenetically unchanged opaline silica may exert still more resistance to compaction and maintain even higher porosities at considerable burial depth (see also later discussion). In this way one may explain the unusually high water contents and porosities at Site $\mathbf{4 7 6}$ and 478 within the depth range of 80 to 170 meters, as well as some high values at Hole 479 (350 m depth).

Apart from these deviations, the trend curves of the holes not influenced by basalt sills fall into a relatively narrow belt. Starting at or near the seafloor, with 60 to $80 \%$ water content or 80 to $>90 \%$ porosity, both values decrease by about $10 \%$ in the uppermost 50 meters. Farther downhole, water contents and porosities are reduced only slightly or remain nearly constant. Between 250 and 350 meters depth, however, a further marked decrease of both parameters can be observed at Site 474 and at Site 479 (below $350 \mathrm{~m}$ ). As already pointed out in the site chapters (this volume), the sediments start to become lithified at this depth range and can be described as weak silty claystones. At this point, biogenic silica is more or less dissolved and reprecipitated as chalcedony, and the formation of authigenic clay minerals may have started.

Since wet-bulk density is directly related to water content and porosity (Keller, 1974; Richards et al., 1974), the graph of the trend lines versus depth (Fig. 2A) can be interpreted in the same way as that of Figure 1. Of course, low values of bulk density now correspond with high water contents and porosities. Starting at the seaffloor (with values between 1.1 and $1.3 \mathrm{~g} / \mathrm{cm}^{3}$ ) the gain of wet-bulk density versus depth is high in the uppermost tens of meters, becoming low farther downhole, particularly for sediments rich in diatoms (Sites 478 through 481 ), as long as the sediments are not affected by basaltic sills in which case the density increases markedly. At Site 474, wet-bulk density increases up to $1.96 \mathrm{~g} / \mathrm{cm}^{3}$ at a depth of 520 to 540 meters below seafloor. The same and even higher values have been found in the contact zone of basaltic sills at much shallower depths (e.g., Holes 477 and 481A), where diagenetic processes also have started to alter the mass physical properties of sediments.

At six holes of Leg 64, wet-bulk density also was measured downhole by logging (Gearhart-Owen Co.), using a gamma-ray source. The compensated density log is produced by moving the receiver by a spring mechanism along the wall of the hole. Thus, large errors caused by washouts or other irregularities of the hole caliper can be avoided. The method cannot be used, however, through the drill pipe in the upper part of the holes. Although the results of the compensated density logs show considerable scatter and tend to be slightly higher (by $0.05-0.1 \mathrm{~g} / \mathrm{cm}^{3}$ ) than the shipboard gravimetric measurements, they reveal the same trends as shown in Figure $2 \mathrm{~A}$ (compare density logs presented in site chapters, this volume).

\section{MASS PHYSICAL PROPERTIES VERSUS EFFECTIVE VERTICAL PRESSURE}

As has been pointed out earlier by many workers (e.g., Lambe and Whitman, 1969; Skempton, 1970; Hamilton, 1976), the depth relationship of mass physical properties often does not satisfactorily explain the data. This is particularly true if basaltic sills are intercalated into sediments. Therefore, some of our data are also plotted against the increase of effective vertical pressure $p_{e}$ (Figs. 2B, 3, 5, and 8). This pressure can be calculated from the wet-bulk density, or total unit weight $\gamma_{t}$ of the sediments saturated with water, minus buoyancy. Then the effective vertical pressure $\Delta p_{e}$ exerted by a certain increment of depth $\Delta h$ is

$$
\Delta p_{e}=\Delta h\left(\gamma_{t}-\gamma_{w}\right)=1.026 \mathrm{~g} / \mathrm{cm}^{3},
$$

where $\gamma_{w}=$ unit weight of seawater.

As shown in Figure 2B, the increase in $p_{e}$ with depth differs markedly from site to site. At Site 477 , where a thick basaltic sill is intercalated at shallow depth, about the same pressure $\left(1.02 \mathrm{MPa}=10.2 \mathrm{~kg} / \mathrm{cm}^{2}\right)$ is exerted 105 meters downhole as is exerted at Site 479 in 300 meters depth. But even without basaltic sills, pressures vary considerably from hole to hole if compared for the same depth. This is one of the reasons why the mass physical property data differ considerably at certain depths below seafloor. Nevertheless, a plot of porosity data versus effective vertical pressure still shows larger deviations from hole to hole than one might expect (Fig. 3). Considering sites without basaltic sills, the curves for Sites 476 and 479 reveal hardly any porosity change in the ranges of $p_{e}=0.4$ to $0.8 \mathrm{MPa}$ or 0.4 to $1.3 \mathrm{MPa}$, respectively. In both cases, as will be discussed, the sediments contain high proportions of biogenic silica, which obviously prevent the reduction of porosity up to a certain critical overburden pressure. If, on the other hand, biogenic silica and possibly also other components are dissolved or recrystallized in the neighborhood of sills, porosity drops to very low values already at relatively low effective pressure (Sites 477, 478, 481). This also occurs on top of basaltic sills (Sites 478 and particularly Site 481 ) where porosity cannot be influenced by the sill load at all. Finally, the curve for Site $\mathbf{4 7 4}$ indicates that porosity (as well as water content and bulk density) strongly decreases within the pressure range of about 1.3 to $2.2 \mathrm{MPa}$. Thus, data confirm the interpretation that, within this range, chemical and mineralogical diagenesis is starting. Pressure alone probably would not produce this drastic change of mass physical properties.

Since water content and wet-bulk density are directly related to porosity (see also Keller, 1974; Richards et al., 1974), these parameters principally show the same relationship to effective vertical pressure as does porosity. 


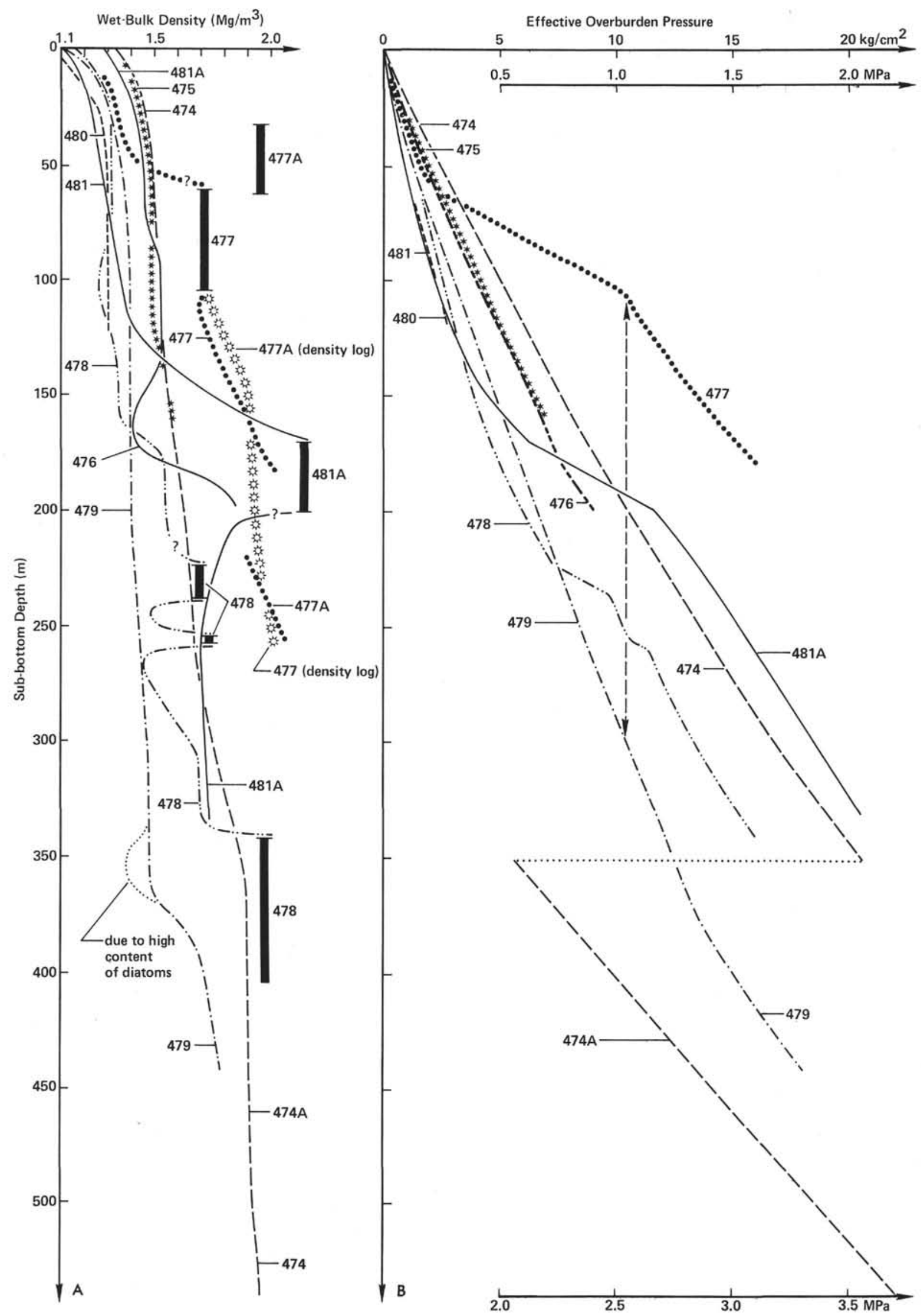

Figure 2. $\mathrm{A}$ = wet-bulk density and $\mathrm{B}=$ vertical effective pressure versus depth (at all sites of Leg 64). 


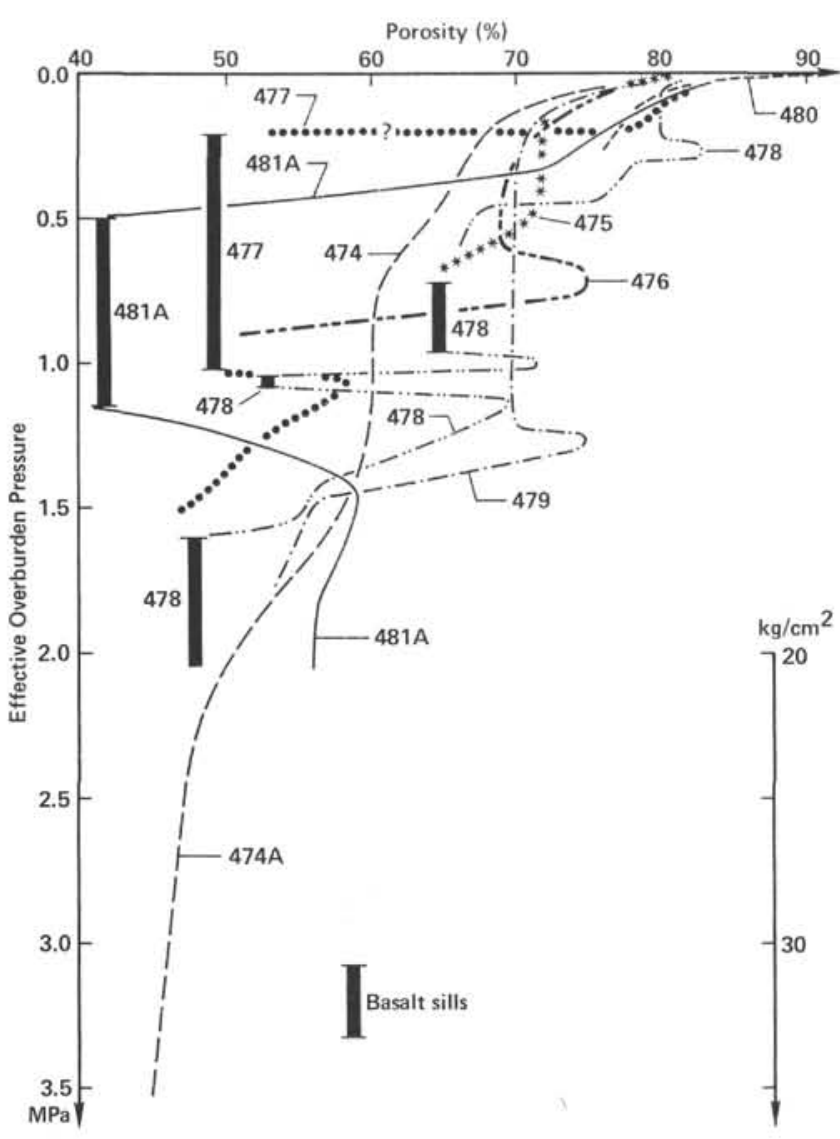

Figure 3. Porosity versus vertical effective pressure (at all sites of Leg $64)$.

\section{VANE SHEAR STRENGTH}

\section{Difficulties and Constraints}

The influence of sampling disturbances on laboratory measurements of physical properties, especially shear strength, is a general problem in soil mechanics (see, for example, Lambe and Whitman, 1969). A critical evaluation of shipboard shear strength measurements has been presented by Lee (1973). For several reasons, the uncorrected vane strength data can deviate considerably from the in situ behavior. Even if a sample is completely undisturbed by coring, one must take into account that the anisotropic in situ stress has been removed and that aboard ship the state of stress within the sediment is transformed to an isotropic condition. The samples tend to expand and to take up pore water to some degree, i.e., they develop negative pore water pressure. Lee calculated the in situ vertical effective stress and the resulting negative pore water pressure, measuring as well the actually existing residual pore water pressure in deep sea cores. From these data he tried to deduce the ratio of the laboratory strength values to the in situ characteristics. For fine-grained sediments from the North Pacific and Bering Sea, often rich in diatoms, he found that the in situ strength values must be higher by a factor of 2 to 3 than measured laboratory strengths. Whether and how these results are affected by the ratio of the frictional to the cohesive component of the shear strength is, however, not known. Because of these uncertainties, and because we did not measure the residual pore water pressure, the following strength data are uncorrected for any kind of sample disturbance.

It should, however, be re-emphasized that a series of measurements was performed on unusually well-preserved cores at Site 481 , obtained by the newly developed hydraulic piston corer (see also site chapter 481). Therefore, the strength-depth relationship of this hole provides an opportunity to check the data of the other sites sampled by the standard drilling method. In any case, measurements of vane shear strength made under undrained conditions on samples in split core liners principally yield values for cohesion and allow hardly any inferences of friction.

\section{Results}

From Figure 4A it appears that the shear strengthdepth plots of all sites except Hole 479 are roughly similar. In the upper 100 to 200 meters, the rate of strength increase is greater than farther downhole. This is explained by the relatively fast increase in cohesion between the sediment particles, which is simultaneous with the marked decrease of water content and porosity in this depth range.

In Holes 477, 478, and 481A the strength-depth curves are strongly affected by intruded basaltic sills, as previously described.

The unusually slow gain of strength versus depth in the uppermost 200 meters of Hole 479 can partially be explained by the high percentage of diatoms in these sediments and to some extent by underconsolidation, as will be discussed. Opaline silica keeps the porosity as high as $70 \%$ (200 m sub-bottom) but also reduces the interparticle cohesion considerably. Below 200 meters, the diatom content decreases (see site chapter 479), and shear strength starts to increase more rapidly downhole until it is again affected by another section rich in diatoms at $\mathbf{3 5 0}$ meters depth. Similarly, the sediments at Site 478 do not gain very much strength between 70 and 200 meters depth. They also contain high percentages of biogenic silica, but in contrast to Hole 479 , many mud turbidites are intercalated, especially in the upper 80 meters. At Site 476, the strength hardly increases in the diatomaceous ooze below 145 meters sub-bottom. Diatoms are also present in the other holes, but there they are only a minor constituent and exert little influence on the shear strength data.

If, in a more general way, vane shear strength is plotted versus effective vertical stress (Fig. 5), the relationship between cohesion and sediment type (as already discussed) becomes more evident. Sections rich in diatoms do not gain much cohesion with increasing vertical stress. Furthermore, it can be seen from Figure 5 that, apart from Site 479, the strength/stress relationship in all holes is rather similar. For a vertical effective pressure of $0.1 \mathrm{MPa}\left(=1 \mathrm{~kg} / \mathrm{cm}^{2}\right)$, uncorrected cohesion is between 0.025 and $0.05 \mathrm{MPa}(=0.25$ and 0.5 $\mathrm{kg} / \mathrm{cm}^{2}$ ). The highest values were found on the best-preserved piston cores of Site 481. But the values of the other holes reach the same order of magnitude. There- 


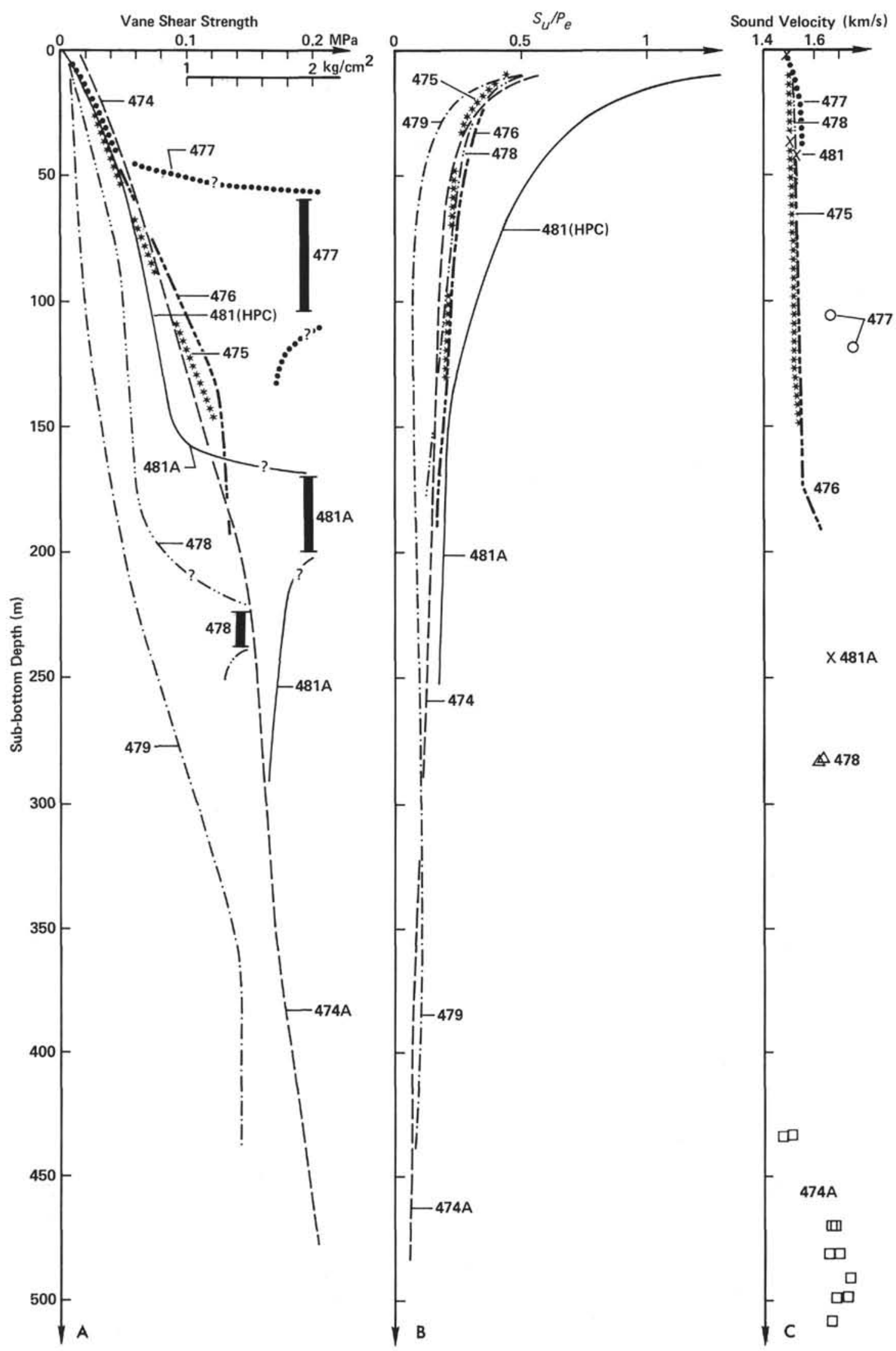

Figure 4. $\mathrm{A}=$ shear strength, $\mathrm{B}=$ ratio of shear strength $\left(S_{u}\right)$ and effective vertical stress $\left(P_{e}\right), \mathrm{C}=$ sound velocity versus depth (at sites of Leg 64). HPC = samples taken by hydraulic piston corer. 


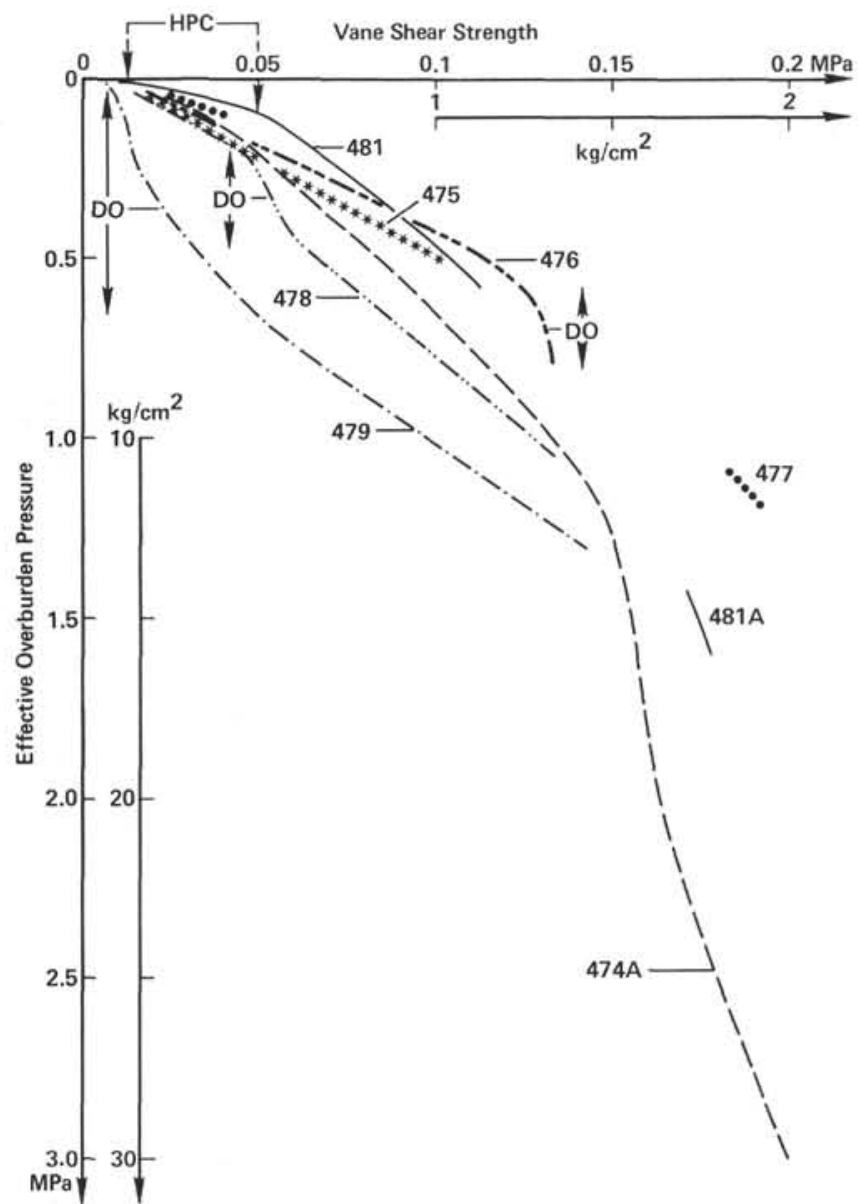

Figure 5. Shear strength versus vertical effective pressure (at all sites of Leg 64). HPC = use of hydraulic piston corer; DO = diatomaeous ooze.

fore, a principal difference between measurements on piston cores and selected sections of cores drilled by the standard drilling method is not clearly visible. At an effective vertical stress of $1 \mathrm{MPa}\left(=10 \mathrm{~kg} / \mathrm{cm}^{2}\right)$, cohesion reaches 0.1 to $0.2 \mathrm{MPa}\left(=1\right.$ to $\left.2 \mathrm{~kg} / \mathrm{cm}^{2}\right)$. With higher stress, cohesion appears to increase more slowly, if cementation of the sediments is excluded. But in this stress range, vane tests made on board Glomar Challenger become unreliable or impossible.

The rapid gain of cohesion in the uppermost section of the sediments is also demonstrated by Figure 4B. Here, the ratio of vane shear strength to vertical effective stress is plotted versus sediment depth. In all cases, cohesion in relation to effective stress is built up much faster in the upper tens to hundreds of meters than farther downhole. Again, this effect is shown best by the data from Hole 481.

Aside from Site 479, sedimentation rate or age of the sediments apparently does not have much influence on the strength-depth relationship (compare Fig. 7). At Sites $477,478,479$, and 481 the sedimentation rate is in the order of 0.5 to $1 \mathrm{~m} / 1000 \mathrm{y}$., whereas at Site 474 it is about $0.2 \mathrm{~m} / 1000$ y., and at Site 475 only $0.04 \mathrm{~m} / 1000$ $y$. The strength-depth plots cannot, however, be grouped into these categories.
Owing to the lack of shear strength data, the influence of basaltic intrusions on the shear strength of the neighboring sediments is not clear. Reduction of porosity certainly also leads to higher cohesion values of the sediments. Some of the strength data measured in sections below the basaltic sills, however, fit well into the general strength/effective stress relationship as shown by Figure 5 .

\section{SHRINKAGE AND POROSITY OF SHRUNKEN SEDIMENTS}

I will not treat in detail the causes and mechanism of volumetric shrinkage of porous sediments. Much has been written on swelling and shrinkage of nonindurated clays and clayey soils on land (e.g., Attewell and Farmer, 1975). Marine pelagic or hemipelagic sediments appear, however, to behave differently in some respects.

The loss of volume by shrinkage depends on several factors: (1) water content and porosity; (2) texture and fabric (microstructure) of sediment; (3) composition of sediment; and (4) strength of bonds between particles to prevent deformation by negative pore water or suction pressure.

The suction pressure within the pores of a sediment is developed during drying. It increases when the pore water is gradually removed, because the capillary forces in small pores are higher than in large ones. Therefore, individual soil samples show a characteristic relationship between moisture content and negative pore water pressure (Philpott, 1970; cit. in Attewell and Farmer, 1975), and the samples continue to shrink until a certain limiting (minimum) water content is reached (see, for example, Lambe and Whitman, 1969). This water content is called "shrinkage limit"; samples with water contents below this limit are in a "solid state" and hardly continue to shrink, although the suction pressure is still considerably raised by further removal of pore water (oven-dried samples have a suction pressure or negative hydraulic head of $10^{7} \mathrm{~cm}$ ).

While aboard the Glomar Challenger, we were able to determine only the total loss of water by oven drying and the volumetric shrinkage $\operatorname{Sh}(\%)$ after the drying of cylindrical samples. From these data initial porosity $n_{i}$ (\%) before drying and shrinkage porosity $n_{d}(\%)$ after drying were calculated, the latter being:

$$
n_{d}=\frac{\left(n_{i}-S h\right) \cdot 100}{100-S h}
$$

The results of these determinations are presented in Figure 6 . They are not very accurate (see methods section), but they do indicate the degree of reduction of porosity which is forced by drying. This process works in a way similar to the application of external pressure and can, therefore, be compared with the result of an effective overburden pressure. The data in Figure 6 clearly show that the residual porosity $n_{d}$ after total drying depends on the type and composition of sediment. Silty clays or clayey silts shrink to a porosity $n_{d}$ of 45 to $55 \%$ (e.g., most samples from Sites 474 and 475 ), whereas sediments rich in diatoms maintain considerably higher 

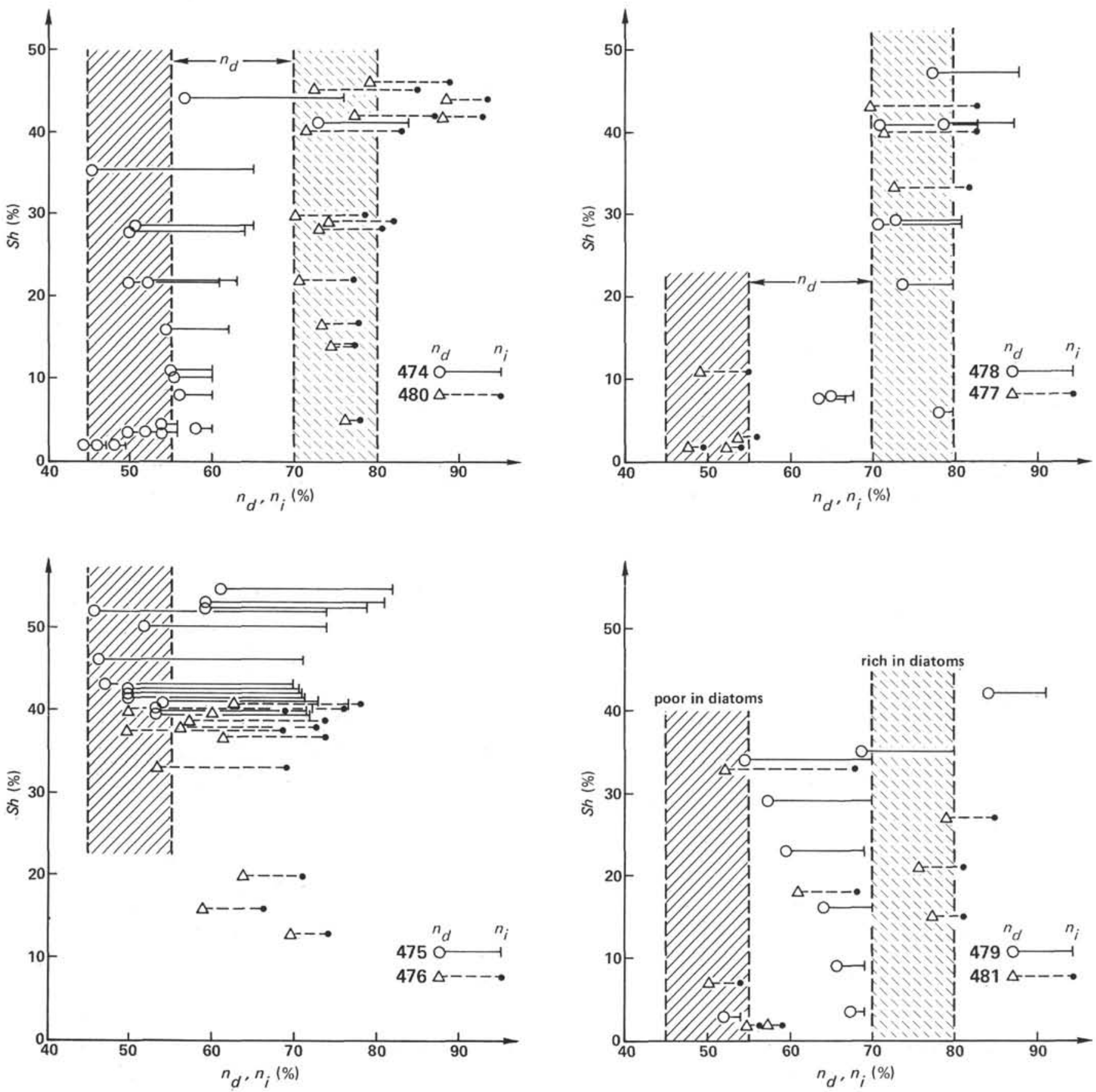

Figure 6. Relationship between initial porosity $\left(n_{i}\right)$, porosity after drying $\left(n_{d}\right)$, and volumetric shrinkage $(S h)$ of samples from different burial depths (ca. Fig. 1C; all sites of Leg 64). Shaded areas signify characteristic porosity values $\left(n_{d}\right)$ of shrunken samples which are poor $\left(n_{d}=45-55 \%\right)$ or rich $\left(n_{d}=70\right.$ to $\left.80 \%\right)$ in biogenic silica.

residual porosities $(70$ to $80 \%$, Sites 478,480$)$. At Sites 476,477 , and 479 , the porosity of shrunken sediments chiefly lies between these two extremes, indicating mixed composition. The strong variability of $n_{d}$ at several sites is caused mainly by the intercalation of mud turbidites, which often contain fewer diatoms than their host sediments (e.g., at Site 481) and show compositional grading (see Einsele and Kelts, this volume).

In order to get the same reduction of porosity by overburden pressure at Site 474 , a sedimentary column of 300 to 500 meters or an effective vertical pressure of
0.16 to $0.33 \mathrm{MPa}$ would be needed (compare Figs. 1B and 2B). At Sites 478 through 481 , where the sediments contain high quantities of diatoms, the depth range for which $n_{i}$ becomes equal to $n_{d}$ differs greatly, but it may reach as deep as about 350 meters. For this depth the corresponding vertical effective pressure is about 1.2 $\mathrm{MPa}$. In other words, during drying the capillary forces within the pores of the sediments exert about the same influence as the sediment load at a burial depth of about 100 meters to several hundreds of meters or an effective vertical pressure of about 0.3 to more than $3 \mathrm{MPa}$. 
Therefore, shrinkage of sediments by drying more or less ceases beyond this depth or pressure range (Fig. 1C). Shrinkage never was found to stop at lower burial depth or at porosities higher than the average $n_{d}$ values characteristic of this type of sediment.

If, on the other hand, the residual porosity of a sample becomes lower than the average $n_{d}$, it is assumed that the sediment is affected by diagenetic processes in addition to the purely mechanical compaction. This may be because of the initiation of solution and reprecipitation, a change in the fabric, and so forth. Some of the samples taken from greater depth (Site 474) and especially from the neighborhood of basalt sills (e.g., Site 477) may fall into this group. But in no case does the porosity $n_{d}$ of shrunken samples drop to values essentially below $45 \%$.

\section{RESULTS OF SOUND VELOCITY MEASUREMENT}

The results from compressional sound velocity measurements on marine sediments have been reported recently in several papers (e.g., Taylor Smith, 1974; Hamilton, 1978, 1979). Because of the limited number of successful measurements in our study, I will do little more here than present the observed data (Fig. 4C).

We found sound velocities in surface sediments to be about $1.5 \mathrm{~km} / \mathrm{s}$ or slightly less, which compares well with the data for siliceous marine sediments summarized by Hamilton $(1978,1979)$. At our sites, the gain in sound velocity with increasing burial depth appears, however, to be slower than reported elsewhere. If porosity is taken into account, however, our results confirm the sound velocity-porosity relationship reported by Taylor Smith (1974) and Wood's equation for finegrained sediments. According to Taylor Smith's figure 2 , sediments with porosities higher than or equal to about $65 \%$ enable sound velocities of only 1.47 to 1.50 $\mathrm{km} / \mathrm{s}$. Since porosities lower than $65 \%$ have been found only at depths greater than 100 meters (Site 475 ) or even 400 meters (Site 479, Fig. 1B), the low velocity gradients at these and some other sites appear to be realistic. The increase of sound velocity to values between 1.6 and 1.7 $\mathrm{km} / \mathrm{s}$ with decreasing porosity in greater depth (i.e., Site $476,190 \mathrm{~m}$; Site $474 \mathrm{~A}, 470-510 \mathrm{~m}$ ), or near the contact above or below basaltic sills, fits well into this sound velocity-porosity relationship.

The results of measurements of sound velocity, wet bulk density, and acoustic impedance on indurated sediment layers from different sites are listed in Table 1 . Trend curves for acoustic impedance versus depth at Sites 475 and 476 are presented in the site chapters.

\section{DISCUSSION AND GENERAL RESULTS}

\section{State of Consolidation}

Marine sediments may be normally consolidated, underconsolidated, or overconsolidated. To discuss their mass physical properties in relation to factors such as sediment composition or burial depth, it is important to know their state of consolidation. There are several ways to evaluate this state both directly and indirectly (see, for example, Bryant et al., 1974; Lambe and Whitman, 1969;
Silva et al., 1976). In many cases, the consolidation test allows the direct determination of preconsolidation stress even if it is higher than the present overburden stress (Lee and von Huene, 1973). The ratio of preconsolidation stress to present effective overburden stress is called the "consolidation ratio." Values higher than 1 indicate a state of overconsolidation; lower values signify underconsolidation. Apparent overconsolidation seems to be a common characteristic of many marine sediments, but several workers have stressed that this may result from diagenetic bonding rather than from the removal of a formerly thicker sedimentary sequence (e.g., Einsele, 1967; Keller and Bennett, 1973; Demars et al., 1979).

We therefore assume that the sediments drilled on Leg 64 in the Gulf of California are not overconsolidated in the sense the term is used in soil mechanics (see, for example, Skempton, 1970). This assumption is supported by the fact that most of the sediments are basinal deposits (including the small ponds at the marginal slope of the tip of Baja California) which can hardly have been affected by strong erosion. Furthermore, aside from the lowermost parts of Holes 476 and 479 , we could detect no stratigraphic gaps within the sedimentary columns.

It is, however, much less certain whether the effects of underconsolidation can be excluded. Silva and his colleagues (1976) have reported a well-documented case of underconsolidation for silty clays of the Bermuda Rise that have accumulated rather rapidly ( 20 to 250 $\mathrm{cm} / 1000 \mathrm{y}$.). Unfortunately, we could not carry out consolidation tests, but the following indirect evidence may support the assumption of underconsolidation in some holes of Leg 64.

1) The sediments of the Guaymas Basin and the lower slope adjacent to this basin have also been rapidly deposited (sedimentation rates higher than 50 to 100 $\mathrm{cm} / 1000 \mathrm{y}$.). They are fine grained and therefore have low permeabilities, and they contain many thick mud turbidites and mass flow deposits.

2) In the sedimentary columns of several holes we observe thick sections where the mass physical properties barely change with depth. In Figure 7 this phenomenon is demonstrated by the porosity values, which, for example, remain constant in Hole 479 over a large depth interval. In the same interval the gain of strength appears in part to be relatively low, indicating that, at least in Hole 479, an excess pore water pressure may have prevented normal consolidation and compaction. The same characteristics, though less pronounced, have been found in the upper part of Hole 478. At the other sites, however, shear strength has normal values and gradients within the intervals of more-or-less constant porosity. At holes with basaltic sills $(477,478,481 \mathrm{~A})$, the combined effects of intrusion mechanics and heat transfer probably have enabled sufficient drainage of pore water (see Einsele, this volume) and thus prevented underconsolidation, at least for some time. Two short intervals lying below the uppermost two sills of Site 478 where surprisingly high porosities have been maintained may be regarded as exceptions (Figs. 1B and 3). We therefore conclude that the basinal sediments are nor- 
Table 1 . Sound velocity $\left(v_{S}\right)$, wet-bulk density, and acoustic impedance of some indurated sediment drilled on Leg 64.

\begin{tabular}{|c|c|c|c|c|c|}
\hline $\begin{array}{l}\text { Core-Section } \\
(\text { level in } \mathrm{cm} \text { ) }\end{array}$ & Rock Type & Orientation & $\begin{array}{c}v_{s} \\
(\mathrm{~km} / \mathrm{s})\end{array}$ & $\begin{array}{l}\text { Wet-Bulk } \\
\text { Density } \\
\left(\mathrm{g} / \mathrm{cm}^{3}\right)\end{array}$ & $\begin{array}{c}\text { Acoustic } \\
1 \text { mpedance } \\
\times 10^{5}\left(\mathrm{~g} / \mathrm{cm}^{2} \cdot \mathrm{s}\right)\end{array}$ \\
\hline $474 \mathrm{~A}-38-1,37$ & arcosic sandstone, cemented & $\perp$ & $\begin{array}{l}4.29 \\
5.04 \\
4.33\end{array}$ & & \\
\hline $476-23, \mathrm{CC}$ & metamorphic sandy siltstone & ? & $\begin{array}{l}5.13 \\
4.92\end{array}$ & & \\
\hline $477 \mathrm{~A}-11-1,15$ & sandstone & $=$ & 1.79 & 1.97 & 3.53 \\
\hline $479-13, \mathrm{CC}$ & carbonate-cemented mudstone & $=$ & 4.40 & 2.57 & 11.3 \\
\hline $479-20-3,82$ & carbonate-cemented mudstone & $=$ & 4.79 & 2.57 & 12.3 \\
\hline $479-29-1,22$ & carbonate-cemented mudstone & $=$ & 4.05 & 2.48 & 10.0 \\
\hline $479-32, \mathrm{CC}$ & carbonate-cemented mudstone & & - & 2.76 & \\
\hline $479-35-4,145$ & silty claystone & 1 & 1.49 & - & \\
\hline $479-40-3,1$ & carbonate-cemented siltstone & & - & 2.77 & \\
\hline $481 \mathrm{~A}-14-4,126$ & $\begin{array}{l}\text { hard silty claystone near } \\
\text { basalt contact }\end{array}$ & $=$ & 4.03 & 2.55 & 10.3 \\
\hline
\end{tabular}
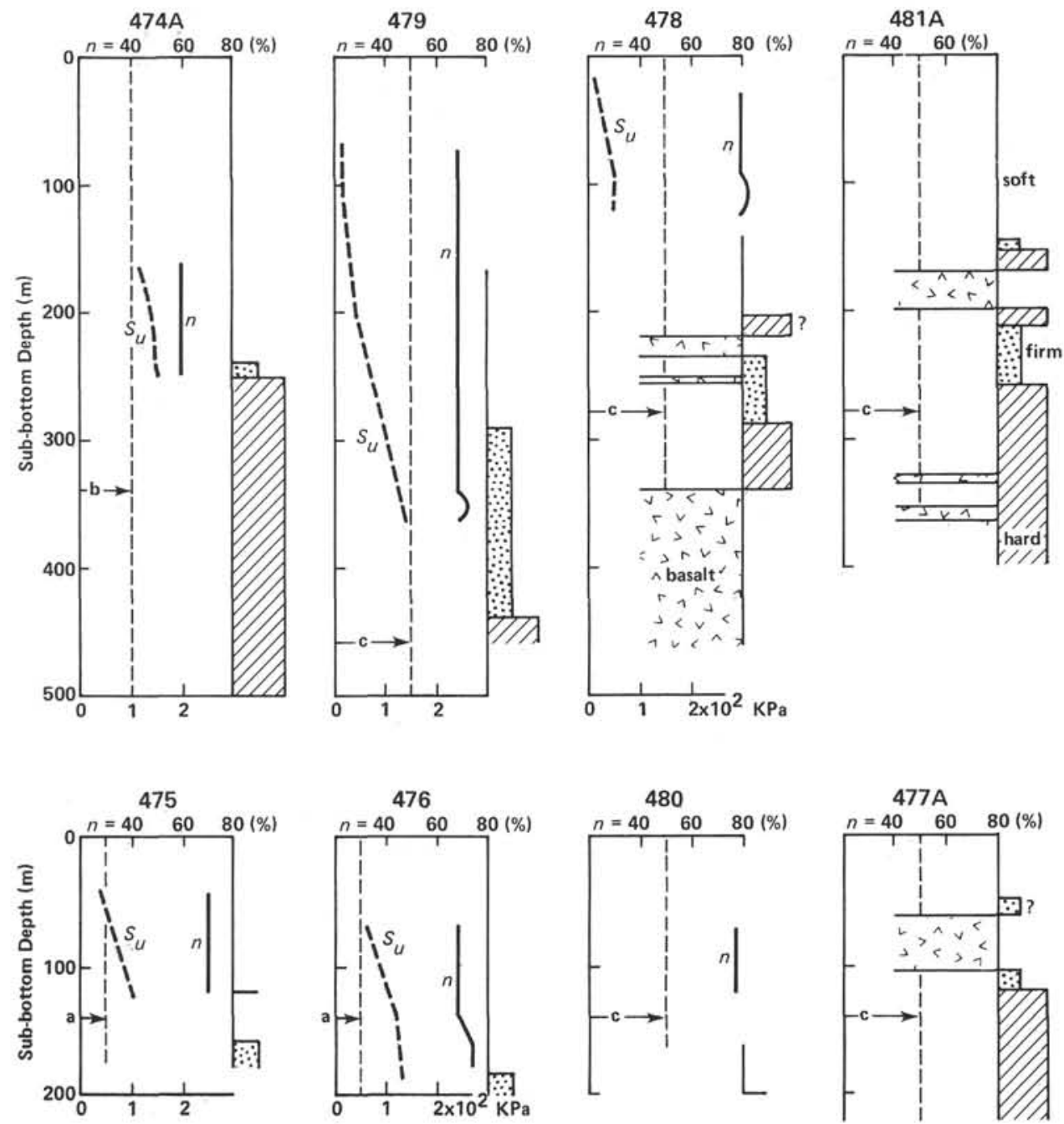

Figure 7. Overview on sediment section with approximately constant porosity $(n)$ but more or less increasing vane shear strength $\left(S_{u}\right)$ within the same depth interval. Letters $\mathrm{a}, \mathrm{b}$, and $\mathrm{c}$ indicate average sedimentation rates (where $\mathrm{a}<50 ; \mathrm{b}=50-200 ; \mathrm{c}>500 \mathrm{~m} / \mathrm{m}$.y.). Hatched zones on the right-hand side of the diagrams indicate induration of sediment (soft, firm, hard mudstone). (Holes 481 A, 480, and 477A are either devoid of sections with constant porosity, or shear strength could not be measured.) 
mally consolidated, an assumption on which the following discussion is based. One must keep in mind, however, that there is no substantial evidence for this assumption and that there do appear to be exceptions.

\section{Influence of Sedimentation Rate or Age}

Among the factors controlling diagenesis and lithification of sediments is age or sedimentation rate. Old and slowly deposited sediments tend to be lithified at a shallower burial depth than do young and rapidly accumulated materials. Because ocean-spreading in the Gulf of California is young, having begun about $4 \mathrm{Ma}$ (see, for example, Moore and Curray, this volume, Pt. 2), its sediments are chiefly Pliocene to Quaternary. And because of several factors, including large source areas and a high relief, the sediments have been deposited comparatively fast. Under such circumstances and in combination with their low carbonate contents (in general $>5-10 \% \mathrm{CaCO}_{3}$ ), little lithification would normally be expected in a depth of a few hundred meters (Tucholke et al., 1976).

Nevertheless, some of the sediments drilled in the Gulf were somewhat firm or hard because diagenesis had already occurred at rather shallow burial depths (see also Kastner et al., this volume, Pt. 2). This process is brought about chiefly by comparatively high heat flow, which generates the dissolution and reprecipitation of opaline silica, as well as by other processes dealt with extensively in this volume, such as the precipitation of carbonate and the growth of other minerals. Here, only a short report of the observed phenomena is given.

In Figure 7 and in subsequent discussion, sediments described as "firm" have vane shear strength values between 0.1 and $0.15 \mathrm{MPa}$ (=1 to $\left.1.5 \mathrm{~kg} / \mathrm{cm}^{2}\right)$. "Hard" materials were split by saw and cracked during the penetration of a vane blade.

Sediments from Sites $474,475,476,479$, and 480 which were not affected by basaltic sill contacts or by high heat flow from a deeper thermal source follow the previously mentioned rule. At Sites 479 and 480 , the sedimentation rate is higher than $500 \mathrm{~m} / \mathrm{m} . \mathrm{y}$., and the sediments start to become firm at about 300 meters subbottom (Fig. 7, not reached at Site 480). At Site 474, where the sedimentation rate is 50 to $200 \mathrm{~m} / \mathrm{m}$.y., sediments are already firm and hard at 240 to 250 meters depth. Where the sedimentation rate decreases to less than $20 \mathrm{~m} / \mathrm{m}$.y. (Sites 475 and 476 ), the material tends to become firm at even shallower burial depths (Fig. 7). Thus, in contrast to Keller and Bennett (1973) or Tucholke et al. (1976), I do not feel that one can exclude the influence of age or accumulation rate on the induration of sediments.

At Sites 477,478 , and 481 , where we found basaltic sills and high heat-flow values, firm and hard sediments occur at the upper and lower contacts and a short distance below the sills (Fig. 7). Here, the induration of sediments is clearly independent of burial depth. But below the sills it may depend on the thickness of the basaltic layer, i.e., on effective overburden pressure, as will be discussed.
Finally, we may ask how lithification is related to the porosity of sediments. Theoretically, it may be possible that a sediment of any porosity may develop interparticle bonds in a first stage of induration. According to our data, firm and hard sediments, poor in diatoms, have porosities no higher than 55 to $60 \%$, and at or near sill contacts they often have porosities less than $50 \%$. Diatomaceous ooze may become firm with a porosity of nearly $70 \%$. It is interesting that these "induration porosities" compare fairly well with the porosity of shrunken samples of the same sediment type (silty clay, $n_{d}=45-55 \%$; diatomaceous ooze, $n_{d}=70-80 \%$; mixtures of both types lying in between. See previous section on shrinkage). This discussion does not include the selected cementation of single sand or silt layers by silica or carbonate which is treated here by Kelts and McKenzie (this volume, Pt. 2).

\section{Mass Physical Properties and Composition of Sediments}

The influence of sediment composition on mass physical properties and the relationship of these to depth or effective overburden pressure have been studied by many workers (e.g., Skempton, 1970; Lee, 1973; Hamilton, 1976). There are two possible ways to approach this question: (1) evaluation of consolidation tests, and (2) use of field data (i.e., field compressibility; Lee, 1973). Here only the second method can be used in plotting void ratio $e$ versus the logarithms of in situ vertical effective stress $p_{e}$ (Fig. 8). Thus, the volumetric response of sediments of different composition to gravitational compaction can be easily derived. In ideal cases, this relationship is represented by a straight line which is called sedimentation-compression curve (Skempton, 1970).

The principal types of sediments drilled on Leg 64 are silty clays or clayey silts, diatomaceous ooze, or mixtures of both types. Most of the many mud turbidites encountered at all sites also belong to these groups, although they usually have somewhat differing physical properties in comparison to the background sediments of the same locality and are, therefore, responsible for the considerable scatter of data at all sites (in addition to the subsequent discussion, see Bachman and Hamilton, 1976; Keller and Lambert, 1972; von Huene et al., 1973; Einsele and Kelts, this volume). These argillaceous sediments poor in diatoms (Sites 474, 475, and most sections of Site 476) display sedimentation-compression curves (Fig. 8, see also Fig. 4) with void ratios or porosities that are within or not far above the range of clays of high plasticity (Skempton, 1970) or highly colloidal clay (Lambe and Whitman, 1969). Similarly, Lee (1973) has found that silty clays of the North Pacific and Bering Sea compare favorably with the Lambe and Whitman curve. Hamilton (1976), however, has pointed out that marine pelagic clays may have considerably higher void ratios and a lower decrease of porosity in the upper 20 meters (pressures about $60-90 \mathrm{KPa}$ ) than indicated by Skempton's curve for clays of high plasticity. To a lesser degree, this is also true of our argillaceous sediments. The general trend of our curves for clayey material is not too far away from a straight-line relationship. Most 


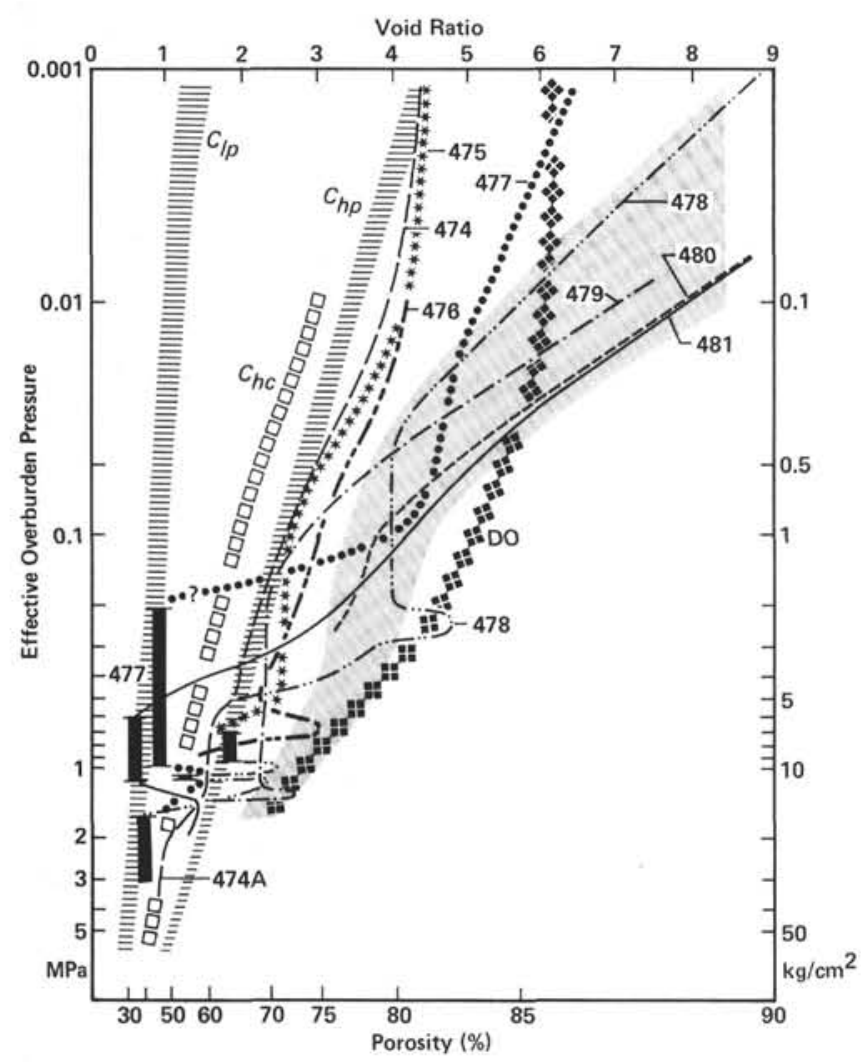

Figure 8. Sedimentation-compression curves (field compressibility) of Leg 64 sediments as compared to some standard curves published earlier: $C_{l p}$ and $C_{h p}$ signify, respectively, lower limit (liquid limit $30 \%$ ) and upper limit (liquid limit $140 \%$ ) of normally consolidated clays of low to high plasticity (after Skempton, 1970); $C_{h c}$ is highly colloidal clay (after Lambe and Whitman, 1969); and DO is diatomaceous ooze of the Bering Sea (Hamilton, 1976). Shaded band summarizes Leg 64 results for diatomaceous oozes.

of the irregularities are caused by changing composition, which may be due to primary variations (Sites 475 and 476) or to diagenesis (Site 474; for example, dissolution of opaline silica and reprecipitation of chalcedony, or the formation of authigenic clay minerals).

Sediments rich in diatoms, or diatomaceous oozes, (Sites 478 through 481 ) show similar characteristics to those described by von Huene (1973), Lee (1973), Silva and Hollister (1973), and Hamilton (1976). They start with an extremely high porosity of 90 to $95 \%$ (void ratio 9-19) at or near the sea bottom, which decreases rapidly to about $80 \%$ (void ratio 4 ) within the upper 20 to 40 meters (pressures about 30-70 KPa). At greater depth or pressure (in our holes down to about $370 \mathrm{~m}$ or up to about $1400 \mathrm{KPa}$ ) they retain, however, very high porosities of 70 to $80 \%$ and display little gradual change of physical properties with depth, because the diatom skeletons are more or less incompressible.

Beyond this depth, however, a state of stress appears to be reached by which the diatoms are crushed, so that within a short interval a much denser packing of particles can be established. Lee (1973) has described the consolidation behavior of diatom oozes in some detail, pointing out that grain crushing may begin at about
$500-700 \mathrm{KPa}$. From the data obtained at Site 479 we can conclude that more than $1400 \mathrm{KPa}$ are necessary to reduce the porosity of diatom ooze, so long as dissolution of opaline silica can be neglected. The shape of our sedimentation-compression curves (Fig. 8, Sites 478 through 481) appear to deviate considerably from that presented by Hamilton (1976). This is the case, however, only for the uppermost 20 meters of sediment, for which we have found higher porosities and porosity gradients with depth. In the deeper parts of the holes, our curves, including their porosity peaks for sections composed of rather pure diatom ooze, compare very well with Hamilton's curve for diatomaceous ooze of the Bering Sea.

\section{Variations of Physical Properties by Sandy and Muddy Turbidites and Other Lithologic Changes}

Turbidites (especially mud turbidites) and, to a smaller degree, deposits from other mass movements are major contributors to the basinal sediments of the Gulf of California. At Sites 474,478 , and 481 , they constitute 60 to $75 \%$ of the total sediment sequence (Einsele and Kelts, this volume). A special study of mass physical properties of mud turbidites has revealed that most of these beds display not only compositional grading, but also a marked grading of mass physical properties. Therefore, it is not surprising that the single data points presented in the site chapters, as well as in a special article on mud turbidites (Einsele and Kelts, this volume), display considerable scatter. Unfortunately, because of core disturbance and some difficulties in recognizing the base and top of each mud turbidite, it was not feasible always to take the samples from the same position of a turbidite (say, the top) or from the host sediments. In other papers it has been pointed out (e.g., von Huene et al., 1973) that sand and diatom content provide the major variables controlling mass physical properties of argillaceous sediments. A high sand content may reduce porosity by about $10 \%$, or a large quantity of diatoms can enhance porosity by 10 to $20 \%$, as compared to a normal hemipelagic silty clay.

As mentioned earlier, our trend lines generally correspond with the middle-to-upper part of mud turbidites. A detailed investigation of selected beds revealed the following minor variations:

1) Shallowly buried mud turbidites at about 10 to 50 meters sub-bottom have porosities $10-20 \%$ lower than their host sediments ( $80-90 \%$ porosity). Their wet bulk density exceeds that of the host sediments (1.2 to 1.3 $\mathrm{g} / \mathrm{cm}^{3}$ ) by up to 0.2 to $0.4 \mathrm{~g} / \mathrm{cm}^{3}$. Of course, there also exist large variations between different types of mud turbidites. Thick turbidites with a high silt and moderate sand content differ much more from the host sediments than do either thinner ones or mud turbidites containing high quantities of diatoms. With increasing depth below seafloor, the difference in physical properties between mud turbidites and host sediments become less pronounced, because finer-grained host sediments are subjected to stronger compaction. At 150 to 400 meters sub-bottom, porosity values vary by about $10 \%$ 
(host sediments having porosities of around 70\%) and bulk densities by about 0.1 to $0.2 \mathrm{~g} / \mathrm{cm}^{3}$ (host sediments $=1.5$ to $1.6 \mathrm{~g} / \mathrm{cm}^{3}$ ).

2) Mass flow deposits were clearly recognized and carefully sampled at Site 481 . As observed on the compensated density log and by gravimetric methods, they also display distinct grading of mass physical properties (see site chapter 481 , this volume). Their porosities may be as much as 5 to $10 \%$ lower and their wet bulk densities about $0.1 \mathrm{~g} / \mathrm{cm}^{3}$ higher than that shown by the average trend lines of Figures $1 \mathrm{~B}$ and $2 \mathrm{~A}$. But intercalated varved diatomites deviate much more from mass flow deposits, as I will point out.

3) There were also minor changes in physical properties between varved and homogeneous light and dark layers of the host sediments from the same depth. At Site 476, a 2-cm-thick light olive-gray nannofossil-rich layer from about 4 meters sub-bottom was compared to a somewhat thicker dark brownish layer rich in diatoms. Both beds constitute common subunits of the PlioceneQuaternary sequence of this area. Water content and porosity of the dark layer were, respectively, about 9 and $5 \%$ higher and, bulk density $0.12 \mathrm{~g} / \mathrm{cm}^{3}$ lower than corresponding values for the light layer. At Sites 480 and 481 , light olive-gray varved diatomites were distinguished from dark gray core sections rich both in diatoms and clay. At all depths, the dark sections have lower porosities (by about 10\%) and higher bulk densities (by $0.1 \mathrm{~g} / \mathrm{cm}^{3}$ ) than the varved diatomites.

All these phenomena contribute to a considerable scatter of physical property data, which is not represented by the trend lines discussed here in more detail. Of course, it would have been preferable to plot trend lines for each type of sediment. But this was not feasible for several reasons, namely: incomplete core recovery, core disturbance, and time constraints.

\section{ACKNOWLEDGMENTS}

I thank the entire Leg 64 scientific and technical party for its cooperation aboard Glomar Challenger. Special thanks are due to J. Pine, who did most of the laboratory work aboard ship. Drs. George H. Keller and Kerry Kelts read the manuscript critically and made valuable comments. The financial support given by the German Research Foundation is gratefully acknowledged.

\section{REFERENCES}

Attewell, P. B., and Farmer, I. W., 1975. Principles of Engineering Geology: London (Chapman and Hall).

Bachman, R. T., and Hamilton, E. L., 1976. Density, porosity, and grain density of samples from Deep Sea Drilling Project Site 222 (Leg 23) in the Arabian Sea. J. Sediment. Petrol., 46(3):654-658.

Bennett, R. H., and Keller, G. H., 1973. Physical properties evaluation. In van Andel, Tj. H., Heath, G. R., et al., Init. Repts. DSDP, 16: Washington (U.S. Govt. Printing Office), 513-519.

Boyce, R. E., 1975. Instructions for Hamilton-Frame Velocimeter. Manual for Shipboard Measurements on Glomar Challenger. 1976. Definitions and laboratory techniques of compressional sound velocity parameters and wet-water content, wet-bulk density, and porosity parameters by gravimetric and gamma ray attenuation techniques. In Schlanger, S. O., Jackson, E. D., et al., Init. Repts. DSDP, 33: Washington (U.S. Govt. Printing Office), 931-958.

1977. Deep Sea Drilling Project procedures for shear strength measurement of clayey sediment using modified Wyke- ham Farrance Laboratory Vane Apparatus. In Barker, P. F., Dalziel, I. W. D., et al., Init. Repts. DSDP, 36: Washington (U.S. Govt. Printing Office), 1059-1068.

Bryant, W. R., Deflache, A. P., and Trabant, P. K., 1974. Consolidation of marine clays and carbonates. In Inderbitzen, A. L. (Ed.), Deep Sea Sediments: New York (Plenum Press), pp. 209-244.

Einsele, G., 1967. Sedimentary processes and physical properties of cores from the Red Sea, Gulf of Aden, and off the Nile Delta. In Richards, A. F. (Ed.), Marine Geotechnique: Urbana (University of Illinois Press), pp. 154-169.

Hamilton, E. L., 1976. Variations of density and porosity with depth in deep-sea sediments. J. Sediment. Petrol., 46:280-300. 1978. Sound velocity-density relations in sea-floor sediments and rocks. J. Acoust. Soc. Am., 63(2):366-377.

1979. Sound velocity gradients in marine sediments. $J$. Acoust. Soc. Am., 65(4):909-922.

Keller, G. H., 1974. Marine geotechnical properties: Interrelationships and relationships to depth of burial. In Inderbitzen, A. L. (Ed.), Deep Sea Sediments: New York (Plenum Press), pp. 77-100.

Keller, G. H., and Bennett, R. H., 1973. Sediment mass physical properties-Panama Basin and northeastern equatorial Pacific. In van Andel, Tj. H., Heath, G. R., et al., Init. Repts. DSDP, 16: Washington (U.S. Govt. Printing Office), 499-512.

Keller, G. H., and Lambert, D. N., 1972. Geotechnical properties of submarine sediments, Mediterranean Sea. In Stanley, D. J. (Ed.), The Mediterranean Sea: Stroudsburg (Dowden, Hutchinson \& Ross), pp. 401-415.

Lambe, T. W., and Whitman, R. V., 1969. Soil Mechanics: New York (John Wiley \& Sons).

Lee, H. J., 1973. Measurements and estimates of engineering and other physical properties, Leg 19. In Creager, J. S., Scholl, D. W., et al., Init. Repts. DSDP, 19: Washington (U.S. Govt. Printing Office), 701-719.

Lee, H. J., and von Huene, R., 1973. Physical properties of deformed sediments from Site 181. In Kulm, L. D., von Huene, R., et al., Init. Repts. DSDP, 18: Washington (U.S. Govt. Printing Office), 897-901.

Perlow, M., Jr., and Richards, A. F., 1977. Influence of shear velocity on vane shear strength. J. Geotech. Eng. (American Society of Civil Engineers), 103(GT1):19-32.

Richards, A. F., 1974. Standardization of marine geotechnics symbols, definitions, units, and test procedures. In Inderbitzen, A. L. (Ed.), Deep-Sea Sediments: New York (Plenum Press), pp. 271-292.

Richards, A. F., Hirst, T. J., and Parks, J. M., 1974. Bulk densitywater content relationship in marine silts and clays. J. Sediment. Petrol., 44(4):1004-1009.

Rocker, K., 1974. Vane shear strength measurements on Leg 27 sediment. In Veever, J. J., Hiertzler, J. R., et al., Init. Repts. DSDP, 27: Washington (U.S. Govt. Printing Office), 425-432.

Silva, A. J., and Hollister, Ch. D., 1973. Geotechnical properties of ocean sediments recovered with giant piston corer, 1. Gulf of Maine. J. Geophys. Res., 78(18):3597-3616.

Silva, A. J., Hollister, Ch. D., Laine, E. P., et al., 1976. Geotechnical properties of deep sea sediments: Bermuda Rise. Mar. Geotechnol. 1(3):195-232.

Skempton, A. W., 1970. The consolidation of clays by gravitational compaction. Q. J. Geol. Soc. London, 125:373-412.

Taylor Smith, D., 1974. Acoustic and mechnical loading of marine sediments. In Hampton, L. (Ed.), Marine Science, (Vol. 1): Physics of Sound in Marine Sediments: New York (Plenum Press), 42-61.

Tucholke, B. E., Edgar, N. T., and Boyce, R. E., 1976. Physical properties of sediments and correlations with acoustic stratigraphy: Leg 35, Deep Sea Drilling Project. In Hollister, C. D., Craddock, C., et al., Init. Repts. DSDP, 35: Washington (U.S. Govt. Printing Office), 229-249.

von Huene, R., Piper, D. J. W., and Duncan, J., 1973. Measurements of porosity in sediments of the lower continental margin, deep-sea fans, the Aleutean trench, and Alaskan abyssal plain. In Kulm, L. D., von Huene, R., et al., Init. Repts. DSDP, 18: Washington (U.S. Govt. Printing Office), 889-895. 